Volume: 12 Issue: 1 Year: 2015

\title{
Analysis of the changes in vegetation of the Sapanca Lake Basin (in Turkey) using multitemporal satellite data ${ }^{1}$
}

\author{
Cercis Ikiel $^{2}$ \\ Derya Evrim Koc ${ }^{3}$
}

\begin{abstract}
The Lake Sapanca Basin is located in an area where urbanization and industrialization is rapidly increasing because of its geographical location. The Sapanca Lake Basin was opened to settlement densely after 1980 due to recreational activities for urbanization and industrialization. The aim of this study is to investigate and evaluate the changes in natural vegetation and settlement caused by the effects of human activities in the Sapanca Lake Basin. For this purpose, Landsat 5 TM (1987) and Landsat 8 (2013) satellite images have been used. These images have been analyzed using ERDAS and ArcGIS software's and this was supported and confirmed by the carried land studies. The results showed that there has been an \% 12.8 decrease in the high density green vegetation areas. It is concluded that the natural vegetation of Sapanca Lake Basin damaged rapidly in the period between the years of 1987-2013.
\end{abstract}

Keywords: Vegetation change; NDVI; Remote sensing; the Lake Sapanca Basin; Turkey

\section{Introduction}

The natural and man-made changes in green vegetation cause degradation, deforestation, loss of biologic diversity, global warming and the increase in natural disasters. Factors such as population growth, urbanization cause uncontrolled and unplanned changes in vegetation. This is a complex issue due to the coexistence of various causes of different levels (Efe et. al., 2012). Hence, causing significant environmental problems which have an influence on the decision making process about the existing and following the environmental management plan (Reis, 2008; Ikiel et al., 2013).

In recent years, multi-time, high resolution satellite images with long term data validation at the same scale have been used commonly in the studies such as the density of agricultural activities,

${ }^{1}$ This paper was presented at the International Congress of the Turkish Association of Geographers, 4 - 6 June 2014 , Mugla, Turkey.

${ }^{2}$ Assistant professor, Sakarya University, Faculty of Science and Arts, Department of Geography, cikiel@sakarya.edu.tr

${ }^{3}$ Research assistant, Sakarya University, Faculty of Science and Arts, Department of Geography, dkilic@sakarya.edu.tr 
Ikiel, C., Koc, D. E. (2015). Analysis of the changes in vegetation of the Sapanca Lake Basin (in Turkey) using multitemporal satellite data. International Journal of Human Sciences, 12(1), 1095-1106. doi: $10.14687 /$ ijhs.v12i1.3186

urbanization rate, shoreline change, forest destruction and vegetation changes (Doker 2012; Ozdemir and Bahadir, 2010; Schucknecht et al., 2013). In remote sensing technology, classification methods are also used to create classes for feeding information about the density of vegetation. Remote sensing is an important medium in order to show the direct or indirect change of green vegetation. The vegetation index is based on different reflectance of vegetation on near-infrared (IR) and visible red bands ( $\mathrm{R}$ ) of the electromagnetic spectrum. Healthy vegetation absorbs most of the visible light and reflects a large portion of near-infrared light. While unhealthy/sparse vegetation reflects more visible and less near-infrared lights. Reflectance on the visible bands depends on the pigments in plant leaves; however, in near-infrared lights, it depends on the cell structure of the plant (Baker 1987). Among the existing vegetation index, the Normalized Difference Vegetation Index (NDVI) is the most commonly used indexes. This index provides information about the change in overall (large and micro-scale) vegetation (Lausch et al., 2013).

The Lake Sapanca Basin, located within the borders of Sakarya and Kocaeli provinces has been opened to intense settlement after 1980s with the effect of recreational activities. As a result, the bearing capacity of the basin in terms of settlement has started to increase. Furthermore, the water quality of the basin has begun to degrade and the natural environment started to be destroyed (Kacmaz, 2010). The aim of this study is to determine the changes in the natural vegetation of the Sapanca Lake Basin due to man-made factors and activities. Using the multitemporal satellite data technique, Landsat 5 TM (1987) and Landsat 8 (2013) satellite images were considered. These images were first confirmed by land studies, then after, have been analyzed using ERDAS and ArcGIS software's. The results show that the natural vegetation of the Sapanca Lake Basin was damaged rapidly in the period between the years of 1987-2013.

\section{Experimental Work}

\section{Study area}

The study area is the Sapanca Lake Basin. This basin is located in the Catalca - Kocaeli section of the Eastern Marmara Region of Turkey. Although this basin is located in the provincial borders of Sakarya and Kocaeli counties, the larger part of it, is within the provincial borders of Sakarya. The Sapanca Lake Basin is located between the eastern longitude of $30^{\circ} 5^{\prime}-30^{\circ} 21^{\prime}$ and the northern latitude of $40^{\circ} 47^{\prime}-40^{\circ} 36^{\prime}$ in the north-west of Turkey (Figure 1). 
Ikiel, C., Koc, D. E. (2015). Analysis of the changes in vegetation of the Sapanca Lake Basin (in Turkey) using multitemporal satellite data. International Journal of Human Sciences, 12(1), 1095-1106. doi: $10.14687 /$ ijhs.v12i1.3186

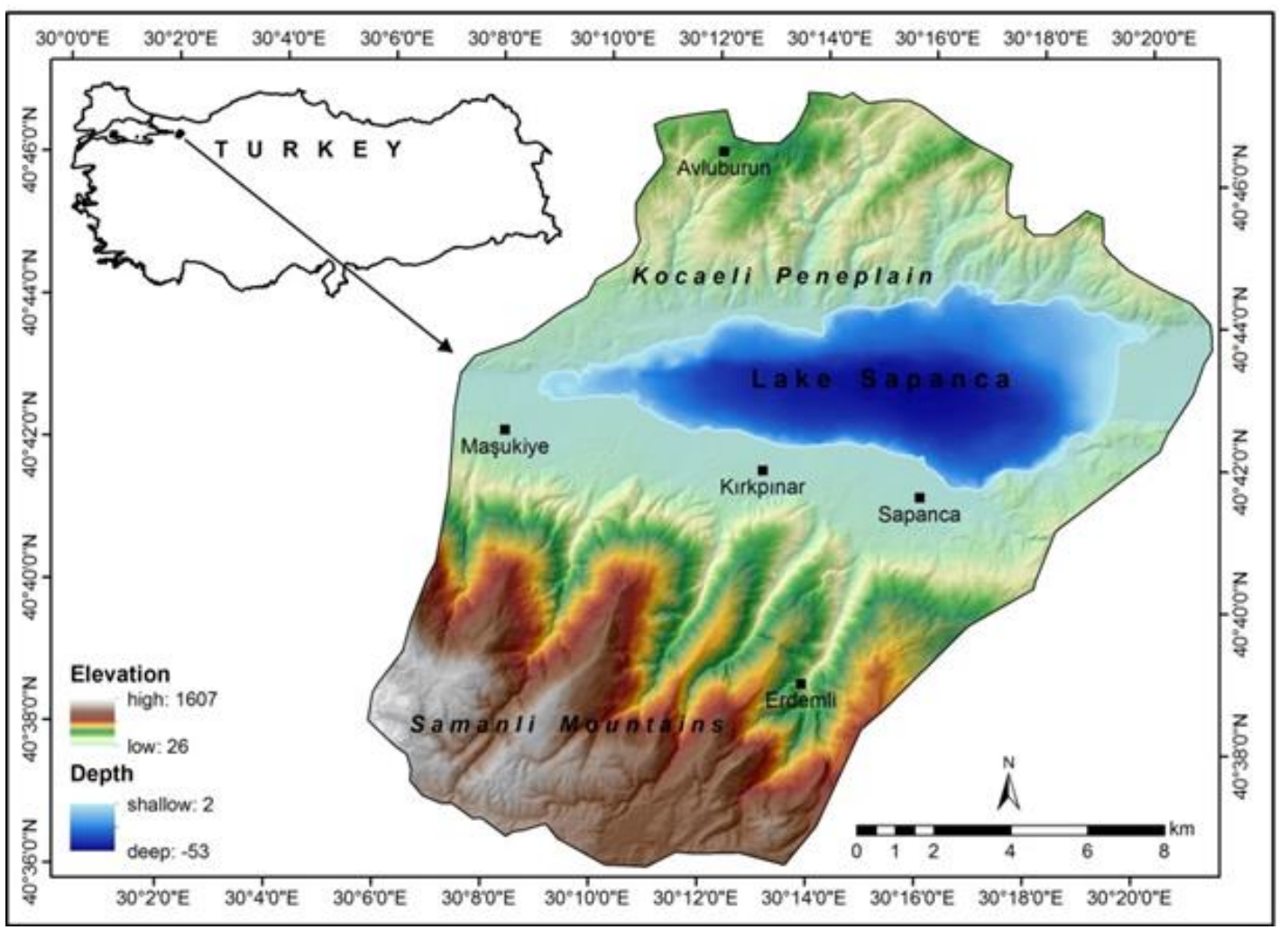

Figure 1. The map of Sapanca Lake Basin (study area)

It is clear from this figure that the Lake of Sapanca Basin is located between the eastern front of Samanli Mountains in the south, Kocaeli Peneplain in the north and Izmit-Sapanca Corridor. The Izmit -Sapanca Corridor stretches between, including the plain and lake inside (Bilgin, 1984). The larger part of this basin is constituted by the fields below $500 \mathrm{~m}$ altitude. The foothills of Samanli Mountains is located in the Basin constitute of the parts above $500 \mathrm{~m}$ altitude. The highest spot of this study area is Kartepe Hill and is with $1602 \mathrm{~m}$ height. The area of Sapanca Lake Basin area is around $46.9 \mathrm{~km}^{2}$ and its deepest point is $53 \mathrm{~m}$ in depth. The Lake of Sapanca is nourished by the streams flowing down the mountains located in its northern and southern parts while, ground waters are rising from the lake bottom. The water of these streams is fresh water. The main streams of the basin are; Karacay, Kurucay, Mahmudiye, Karanlik, Istanbul, Cinarlik, Gurgenli, Balikhane, Esme, Aygir and Arifiye. The average yearly temperature is $13.5^{\circ} \mathrm{C}$ and it reflects the features of the thermal regime type of Marmara region (Kocman, 1993). The average annual precipitation in the lake basin differs between $700-900 \mathrm{~mm}$. The precipitation features are similar to the precipitation regime type of the Black Sea (Ikiel, 2005). The winter in the lake basin is warm and rainy, however the summer season is not dry and hot as in the Mediterranean climate. This type of climate has an effect on the vegetation, therefore the elements of Mediterranean and Black sea climates prevail 
Ikiel, C., Koc, D. E. (2015). Analysis of the changes in vegetation of the Sapanca Lake Basin (in Turkey) using multitemporal satellite data. International Journal of Human Sciences, 12(1), 1095-1106. doi: $10.14687 /$ ijhs.v12i1.3186

alongside. Lake of Sapanca Basin is quite rich in terms of vegetation (Avci, 1993). This area is within Euxine province of Euro-Siberia Phytogeographic Region.

In this study, the Hygrophilous forests take large space of the area under investigation. The main tree and scrub species that are common in this area include: Fagus orientalis, Quercus petraea, Castanea sativa, Acer campestre, Carpinus betulus, Populus tremula, Alnus glutinosa, Tillia tomentosa, Corylus avellana, Cornus mas, Prunus $x$ domestica and Rhododendron ponticum (Atalay, 1994).

Apart from the climate of this area, the changes in population and settlement characteristics have its large influences on the vegetation. This covers the increase in summer holiday camps and their gradual conversion into permanent houses (Kacmaz and Ikiel, 2007). Furthermore, this area is located in Marmara Region, which is the most affected place from urbanization and industrialization in our country.

The population of Sapanca and Kartepe settlements that constitute the lake basin has shown a $\% 100$ increase since 1985 to 2013 (Figure 2).

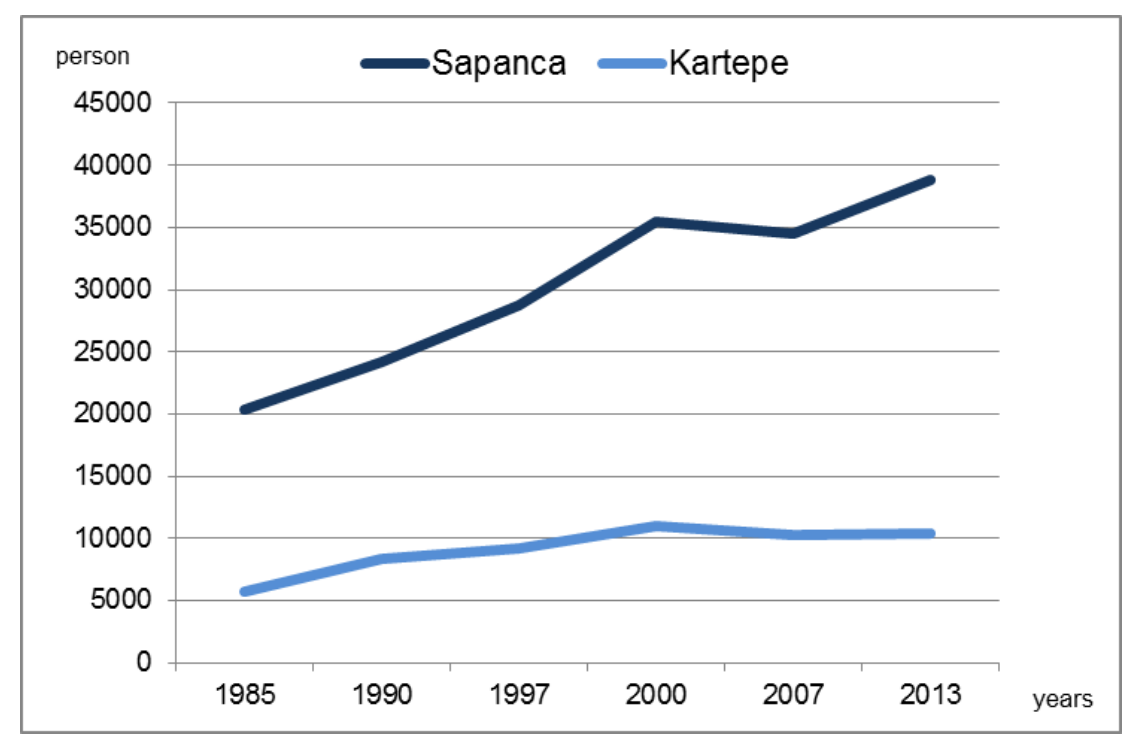

Figure 2. Population change of Lake of Sapanca Basin

\section{Data and Methods}

\section{Data}

For this study, the essential data are the change of vegetation and its density and the morphological structure, vegetation distribution and population structure and features. Data for the change of vegetation and its density were provided by satellite images from Landsat 5 TM (1987) and Landsat 8 (2013) supplied by US Geological Survey (USGS) Earth Resources Observation and Science 
Ikiel, C., Koc, D. E. (2015). Analysis of the changes in vegetation of the Sapanca Lake Basin (in Turkey) using multitemporal satellite data. International Journal of Human Sciences, 12(1), 1095-1106. doi: 10.14687/ijhs.v12i1.3186

(EROS) Data Center (http://glovis.usgs.gov). The Characteristics of the satellite data used for land cover change mapping is with the cloud cover lower than \% 10 (Table1).

Table 1. Characteristics of the satellite data used for land cover change mapping in the study area

\begin{tabular}{lcc} 
Type of imagery & Date & Spatial resolution (m) \\
\hline Landan 5 TM & 01.08 .1987 & 30 \\
Landsat 8 & 25.09 .2013 & 30 \\
\hline
\end{tabular}

The morphological structure, vegetation distribution and population structure and features data were obtained by the sample points (.aoi), topographic maps (G24) at the scale of 1:100.000 provided by General Command of Mapping, Forest management plans of the chiefdoms of Suadiye, Izmit, Sapanca, Adapazari from General Directorate of Forestry and total population data of 1985-1990-1997-2000-2007-2013 (Turkish Statistical Institute (TUIK). Apart from this land survey we carried out in which the reference points were chosen using a hand held GPS.

\section{Method}

The analyses of the vegetation change were carried out in four phases or steps. These are, (1) image preprocessing (geometric correction), (2) determining the classification of green vegetation and NDVI, (3) supervised classification and (4) accuracy analysis.

\section{Image Pre-Processing}

In this step, firstly, the bands having similar features and wavelengths of the satellite images with different number of bands have been combined separately for both images. In this process, band ordering of Landsat 5 TM image has been taken into account. Then, the geometric correction of satellite images has been carried out using "linear polynomial method" and taking the topographic maps at the scale of 1:100.000 as reference. In this process, 4 clearly discernible ground control points have been chosen for each satellite image. As a result of rectifier process, the total amount of error margin (RMSE- Root Mean Square Error) has been considered to be under 1.0 pixel. The geographical reference of both satellite images has been defined as Universal Transverse Mercator UTM, WGS- 84. For further steps in the analysis, the satellite images have been considered at the border line of the area under study. 
Ikiel, C., Koc, D. E. (2015). Analysis of the changes in vegetation of the Sapanca Lake Basin (in Turkey) using multitemporal satellite data. International Journal of Human Sciences, 12(1), 1095-1106. doi: 10.14687/ijhs.v12i1.3186

Normalized Difference Vegetation Index and Determining Green Vegetation Classes:

Band arithmetic named as Normalized Difference Vegetation Index (NDVI) is based on nearinfrared (IR) and visible red (R) bands of electromagnetic spectrum. A Digital Number value is the value of one pixel on a data band. For the calculation of NDVI value, Digital Number values (DN) of different bands were used. In this technique the measurement is based on A Digital Number value changes depending on the amount of radiation absorbed by the atmosphere and ground surface and the remain reflection back to the sensor. Algorithm of Normalized Difference Vegetation Index can be defined (Akkartal et al., 2005; Ozdemir and Turoglu, 2007; Peng et al., 2012; Tunay and Atesoglu, 2008);

\section{$N D V I=(I R-R) /(I R+R)$}

The NDVI image results in a number that ranges from -1 to +1 . The negative value describes an area where there is no vegetation like cloud, rock or water. The positive value means that the area is covered with vegetation. As the value gets closer to +1 , it indicates the highest possible density of green vegetation (Duran, 2007; Peng et al., 2012).

From our data, four different area classes were observed. These areas are: the high density of green vegetation (average NDVI value over 0.7 ), medium density of green vegetation (average NDVI value between 0.7 - 0.04), low density of green vegetation (average NDVI value $0.4-0.0$ ) and nonexistent green vegetation (Akkartal et al., 2005; Peng et al., 2012; Tunay and Atesoglu, 2008).

\section{Supervised Classification}

The Supervised classification was carried out choosing the available sample areas in the image data by image processing algorithm or making use of predetermined spectral features. In this process, over 70 homogeneously distributed sample areas of interest (.aoi) have been determined. In the study area out of total 4 classes of the locations where the density of vegetation is different. During the supervised classification process, aoi function has been focused to reduce the possibility of intermingling of classes (Ikiel et al., 2012; Ikiel et al., 2013; Ustaoglu, 2012). All images were independently classified using the supervised classification method of maximum likelihood algorithm. Then after classification process, all sample areas have been classified according to class types determined by "recode" function. A $5 \times 5$ median filter has been implemented in order to eliminate the unnecessary information in the classified image. 
Ikiel, C., Koc, D. E. (2015). Analysis of the changes in vegetation of the Sapanca Lake Basin (in Turkey) using multitemporal satellite data. International Journal of Human Sciences, 12(1), 1095-1106. doi: $10.14687 /$ ijhs.v12i1.3186

\section{Accuracy Analysis}

The Function of Accuracy Analysis was implemented to evaluate the accuracy of classified images. In this process, over 70 random reference control points have been determined for 4 classes on the map of the study area. Point spreads have been chosen in direct proportion to areal distribution of classes. Confusion matrix data, accuracy table and kappa statistics were obtained. The confusion matrix is the most common layout data to determine the accuracy of classification results. Hence, the pixels falling on the reference data of the classified pixels belong was determined and the matrix is formed by collocating the numbers in columns. Furthermore, the confusion matrix was used as the base to realize the evaluation of overall accuracy, user's and producer's accuracy and kappa analysis (Guler et al., 2007; Jensen, 1996). The overall accuracy was calculated by dividing the total number of pixels to the total correct numbers in the confusion matrix (Congalton, 1991; Lui et al., 2010). In overall accuracy, a high accuracy for one class can mask the bad performance of other classes. The criterion of user's and producer's accuracy of each class was calculated in order to prevent this case. The producer's accuracy refers to the possibility of accurate classification of reference pixels and user's accuracy refers to the ratio of the classified pixels in the reference data of that class (Congalton, 1991; Lui et al., 2010).

Finally, in the accuracy analysis of the kappa statistics which is a multivariate technique was used for the control of the accuracy analysis (Congalton, 1991; Guler, et al., 2007; Jensen, 1996).

\section{Results and Discussions}

\section{Accuracy Analysis}

Table 2 presents the results of accuracy assessment of the 1987 land produced from Landsat5. It is clear from this table that there are four classes. These classes are, high density, medium density, low density and nonexistent vegetation. The sites characterized by high density vegetation represents forests, medium density of green vegetation represents cultivated areas and meadows, low density of green vegetation corresponds to residential areas and nonexistent vegetation corresponds to stones, clouds and water mass.

75 special signature files have been defined for the vegetation change map of 1987. Overall accuracy rate has been determined as \% 86.6 overall kappa statistics as 0.81 . The producer's accuracy in the classes except low and medium density of green vegetation sites is over $\% 85$. User's accuracy values excluding low density of vegetation sites have been determined over $\% 75$ (Table 2). 
Ikiel, C., Koc, D. E. (2015). Analysis of the changes in vegetation of the Sapanca Lake Basin (in Turkey) using multitemporal satellite data. International Journal of Human Sciences, 12(1), 1095-1106. doi: $10.14687 /$ ijhs.v12i1.3186

Table 2. Accuracy assessment of the 1987 land cover map produced from Landsat 5

\begin{tabular}{lcccccc}
\hline $\begin{array}{l}\text { Class names } \\
\text { (1987) }\end{array}$ & $\begin{array}{c}\text { Reference } \\
\text { Totals }\end{array}$ & $\begin{array}{c}\text { Classified } \\
\text { totals }\end{array}$ & $\begin{array}{c}\text { Number } \\
\text { correct }\end{array}$ & $\begin{array}{c}\text { Producer's } \\
\text { accuracy (\%) }\end{array}$ & $\begin{array}{c}\text { User's } \\
\text { accuracy (\%) }\end{array}$ & $\begin{array}{c}\mathbf{k} \\
\mathbf{\%}\end{array}$ \\
\hline $\begin{array}{l}\text { High density of green } \\
\text { vegetation }\end{array}$ & 22 & 20 & 19 & $86.36 \%$ & $95.00 \%$ & 92.9 \\
$\begin{array}{l}\text { Medium density of green } \\
\text { vegetation }\end{array}$ & 26 & 25 & 22 & $84.62 \%$ & $88.00 \%$ & 81.6 \\
$\begin{array}{l}\text { Low density of green } \\
\text { vegetation }\end{array}$ & 18 & 20 & 15 & $83.33 \%$ & $75.00 \%$ & 67.1 \\
$\begin{array}{l}\text { Nonexistent green vegetation } \\
\text { Totals }\end{array}$ & 9 & 10 & 9 & $100.00 \%$ & $100.00 \%$ & 88.6 \\
\hline Overall classification accuracy= $86.67 \%$ & 75 & 65 & Overall Kappa statistics= 0.8164 & \\
\hline
\end{tabular}

75 special signature files have been defined for the vegetation change map of 2013. Overall accuracy rate has been determined as \% 85.3, overall kappa statistics as 0.80 . The producer's accuracy in the classes except medium density of green vegetation sites ( $\% 78)$ is over $\% 80$. User's accuracy values excluding high density and medium density of green vegetation sites have been determined over $\% 85$ (Table 3).

Table 3. Accuracy assessment of the 2013 land cover map produced from Landsat 8

\begin{tabular}{lcccccc}
\hline $\begin{array}{l}\text { Class names } \\
\text { (2013) }\end{array}$ & $\begin{array}{c}\text { Reference } \\
\text { Totals }\end{array}$ & $\begin{array}{c}\text { Classified } \\
\text { totals }\end{array}$ & $\begin{array}{c}\text { Number } \\
\text { correct }\end{array}$ & $\begin{array}{c}\text { Producer's } \\
\text { accuracy (\%) }\end{array}$ & $\begin{array}{c}\text { User's } \\
\text { accuracy (\%) }\end{array}$ & $\begin{array}{c}\mathbf{k} \\
\mathbf{0}\end{array}$ \\
\hline $\begin{array}{l}\text { High density of green } \\
\text { vegetation }\end{array}$ & 21 & 20 & 19 & $90.48 \%$ & $95.00 \%$ & 93 \\
$\begin{array}{l}\text { Medium density of green } \\
\text { vegetation }\end{array}$ & 19 & 20 & 15 & $78.95 \%$ & $75.00 \%$ & 66.5 \\
$\begin{array}{l}\text { Low density of green } \\
\text { vegetation }\end{array}$ & 21 & 20 & 17 & $80.95 \%$ & $85.00 \%$ & 79.1 \\
$\begin{array}{l}\text { Nonexistent green vegetation } \\
\text { Totals }\end{array}$ & 14 & 15 & 13 & $92.86 \%$ & $86.67 \%$ & 83.1 \\
\hline Overall classification accuracy $=85.33 \%$ & 75 & 64 & Overall Kappa statistics $=0.8033$ & \\
\hline
\end{tabular}

It is clear from the accuracy analysis in Table 2 and Table 3 that, the lowest classification accuracy detected is in medium density and low density of green vegetation sites. Heterogeneous character of these classes can be stated as the reason behind of this case. The increase of the cultivated areas and the sites are due to ornamental plants which were grown in the medium density of green vegetation areas and due to the existence of some classes whose reflectance rate similar to each other in both classes could be shown as the cause of that. The highest classification accuracy is for no vegetation 
Ikiel, C., Koc, D. E. (2015). Analysis of the changes in vegetation of the Sapanca Lake Basin (in Turkey) using multitemporal satellite data. International Journal of Human Sciences, 12(1), 1095-1106. doi: $10.14687 /$ ijhs.v12i1.3186

areas. The underlying factor is the water mass in the class and the homogeneous character of rocky areas.

\section{Vegetation Change Analysis}

Table 4 and Figure 3 presents the area classes and their rate of change obtained from NDVI classification of 1987 and 2013 years satellite images on hectare basis area.

Table 4. NDVI classification for 1987 and 2013 images

\begin{tabular}{|c|c|c|c|c|c|c|}
\hline \multirow[b]{3}{*}{ Class names } & \multicolumn{4}{|c|}{ Years } & \multirow{2}{*}{\multicolumn{2}{|c|}{$\begin{array}{c}\text { Change } \\
2013-1987\end{array}$}} \\
\hline & \multicolumn{2}{|c|}{1987} & \multicolumn{2}{|c|}{2013} & & \\
\hline & ha & $\%$ & ha & $\%$ & ha & $\%$ \\
\hline High density of green vegetation & 16175.3 & 60.1 & 12732.9 & 47.3 & -3442.4 & -12.8 \\
\hline Medium density of green vegetation & 5182.4 & 19.2 & 7250.6 & 26.9 & 2068.2 & 7.7 \\
\hline Low density of green vegetation & 1040.6 & 3.9 & 2392.7 & 8.9 & 1352.1 & 5.0 \\
\hline Nonexistent green vegetation & 4525.7 & 16.8 & 4547.7 & 16.9 & 22.1 & 0.1 \\
\hline Totals & 26923.9 & & 26923.9 & & & \\
\hline
\end{tabular}

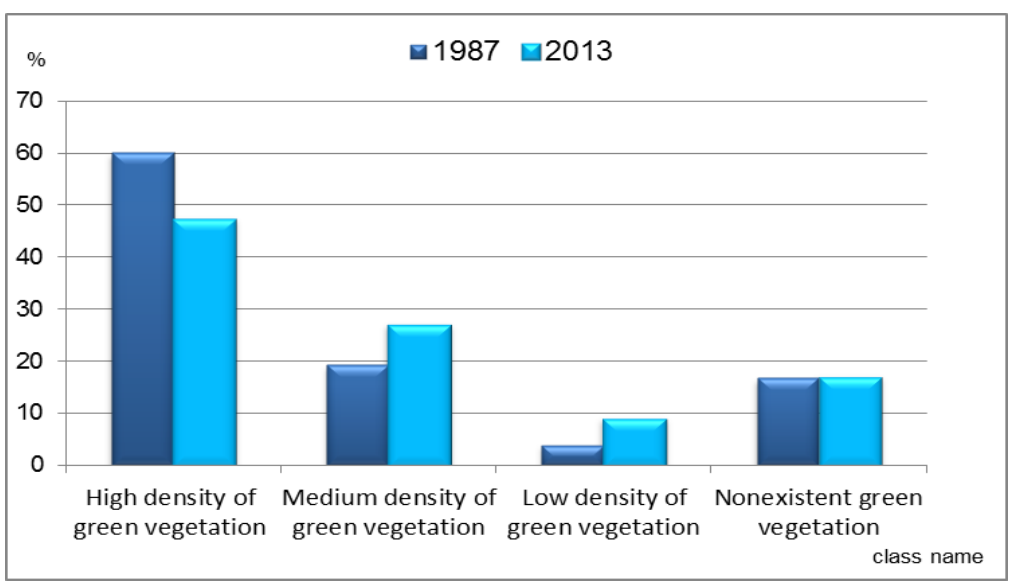

Figure. 3. The ratio of the change of NDVI classes between 1987 - 2013 years

The classes and the satellite images have been interpreted visually according to the results of NDVI. Although sufficient amount of homogeneously distributed areas (.aoi) has been determined, areas (ways) that should have been included in no vegetation areas having similar reflectance value to each other have been included in low density of green vegetation class as a result of the supervised classification process since it is classified in this group. The satellite images of 1987 - 2013 have 
Ikiel, C., Koc, D. E. (2015). Analysis of the changes in vegetation of the Sapanca Lake Basin (in Turkey) using multitemporal satellite data. International Journal of Human Sciences, 12(1), 1095-1106. doi: $10.14687 /$ ijhs.v12i1.3186

been classified to be able to interpret the change visually and statistically (Figure 4, 5). It is clear from these figures and table 4 that the highest change been in the high density of green vegetation areas. There has been an \% 12.8 decrease from 16175.3 hectares to 12732.9 hectares in the high density of green vegetation areas. The main reason for this is the forest destruction and the increase of human population effects.

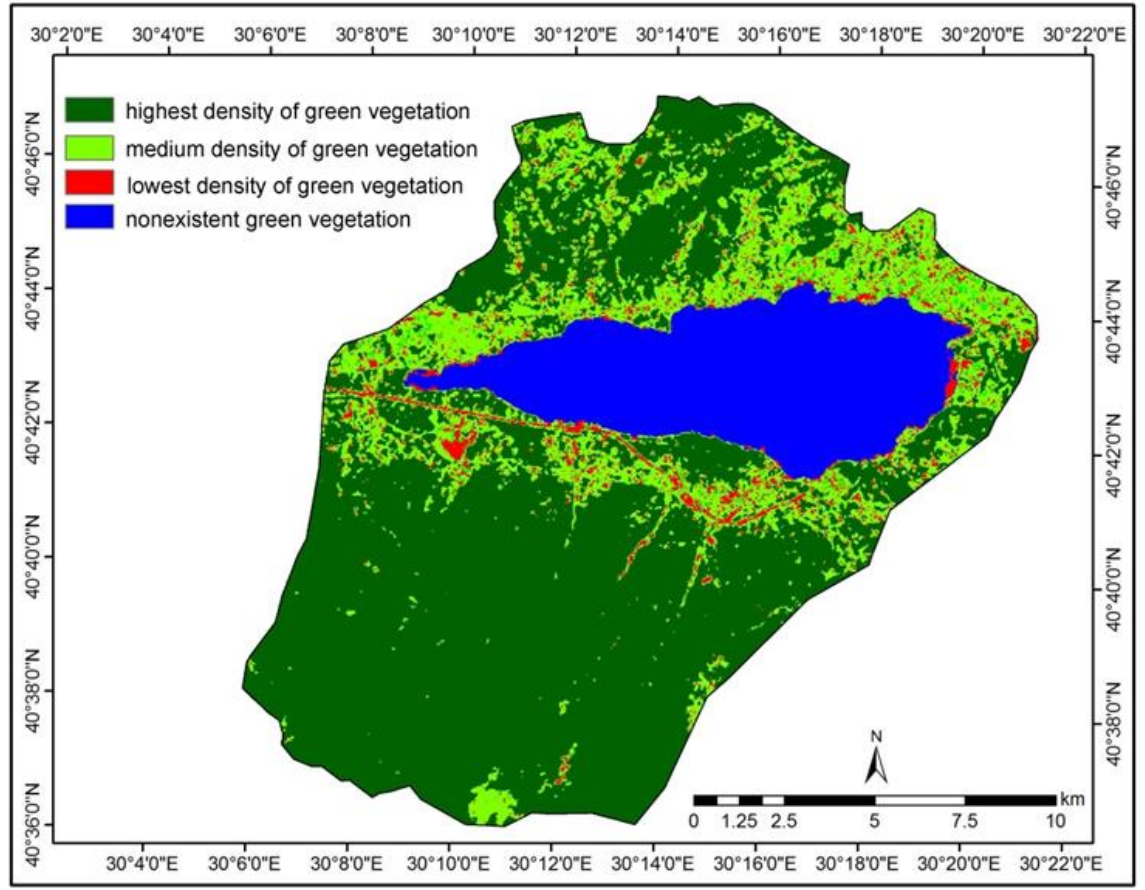

Figure 4. NDVI classification map of 1987 image

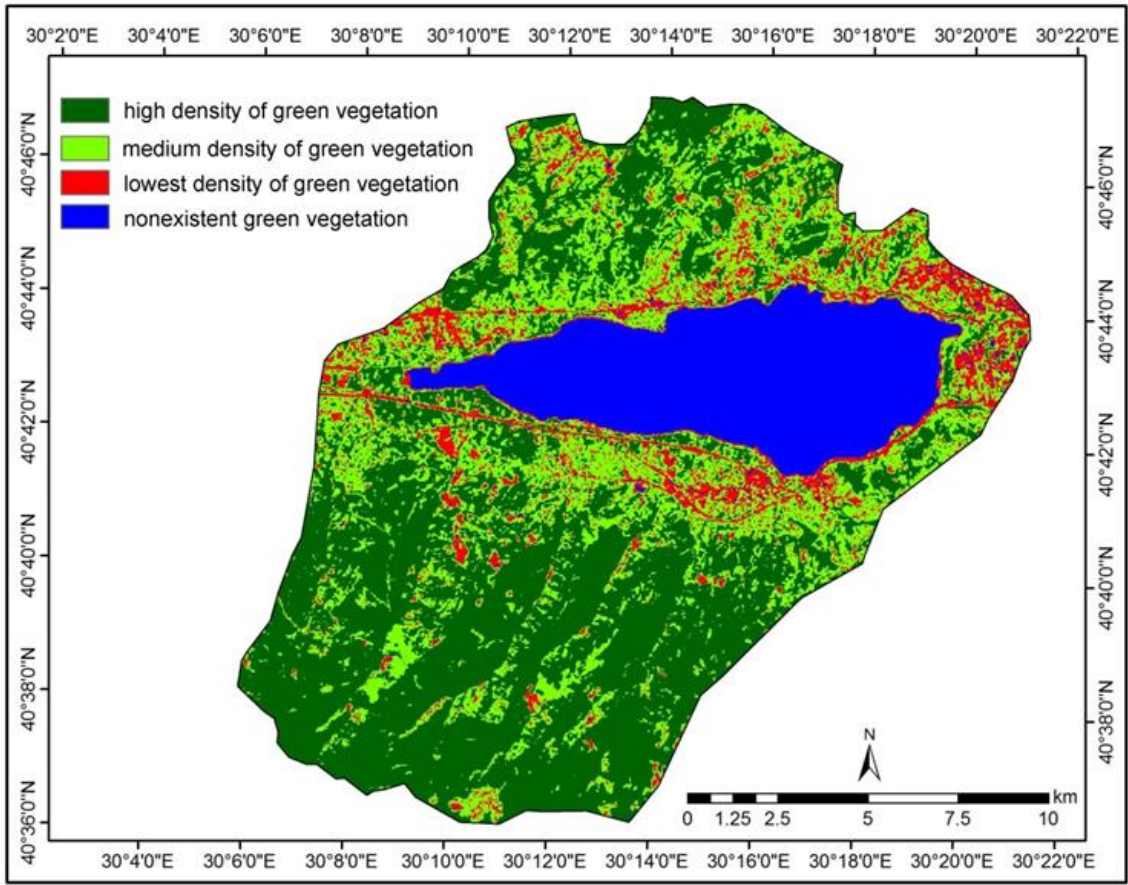

Figure 5. NDVI classification map of 2013 image 
Ikiel, C., Koc, D. E. (2015). Analysis of the changes in vegetation of the Sapanca Lake Basin (in Turkey) using multitemporal satellite data. International Journal of Human Sciences, 12(1), 1095-1106. doi: $10.14687 /$ ijhs.v12i1.3186

There is an \% 7.7 increase from 5182.4 to 7250.6 hectares and $\% 5$ increase from 1040.6 to 2392.7 hectares in the medium density and low density of green vegetation areas respectively. This could be explained by the increase of human effect because of the growth in urbanization and industrialization. In another words, the conversion of cultivated areas into residential areas as second house construction. Since no vegetation areas have more stable state, a significant change has not been observed.

\section{Conclusions}

In this study, the vegetation changes between 1987 - 2013 in Lake of Sapanca Basin has been studied by the techniques of Remote Sensing (RS), geographic information system (GIS), Landsat 5 TM, Landsat 8 satellite images and the following conclusions were reached.

-The overall accuracy of both satellite images are over \% 80 and their kappa statistics are over 0.80 .

- There has been \% 12.8 decrease from 16175.3 hectares to 12732.9 hectares in the "bigh density of green vegetation" areas and \% 7.7 increase from 5182.4 to 7250.6 hectares and \% 5 increase from 1040.6 to 2392.7 hectares in "medium density" and "low density of green vegetation" areas, respectively.

- The main element affecting the development in the basin is the emergence of a class with high income level that sees recreational activities as a need after urbanization and industrialization activities.

- Consequently, due to the geographical and commercial activities of the Sapanca lake region, the natural vegetation is being destructed and replaced by industrial enterprises. This finding is an alert informs about the possible change trend in future. Therefore, human activities in the research area should be followed-up for sustainable development.

\section{References}

Akkartal, A., Turudu, O. \& Erbek, S. F. (2005). Cok zamanli uydu goruntuleri ile bitki ortusu degisim analizi. TMMOB Harita ve Kadastro Muhendisleri Odast 10. Turkiye Harita Bilimleri Bilimsel ve Teknik. Kurultayi, 28 Mart-1 Nisan 2005, Ankara.

Atalay, I. (1994). Turkiye vejetasyon cografyasi. Izmir: Ege Universitesi Basimevi.

Avci, M. (1993). Turkiye'nin flora bolgeleri ve Anadolu Diagonali’ne cografi bir yaklasim. Turk Cografya Dergisi, 28, 225-248.

Bilgin, T. (1984). Adapazar Ovasi ve Sapanca Olugunun aluviyal morfolojisi ve kuaternerdeki jeomorfolojik tekamulu. Istanbul: Istanbul Universitesi Edebiyat Fakultesi Yayinlari, 2571.

Congalton, R. G. (1991) A review of assessing the accuracy of classifications of remotely sensed data. Remote Sens. Environ., 37, 35-46.

Duran, C. (2007). Uzaktan algilama teknikleri ile bitki ortusu analizi. Doa Dergisi, 13, 45-67. 
Ikiel, C., Koc, D. E. (2015). Analysis of the changes in vegetation of the Sapanca Lake Basin (in Turkey) using multitemporal satellite data. International Journal of Human Sciences, 12(1), 1095-1106. doi: $10.14687 /$ ijhs.v12i1.3186

Efe, R., Soykan, A., Curebal, I. \& Sonmez, S. (2012) Land use and land cover change detection in Karinca River Catchment (NW Turkey) using GIS and RS techniques. Journal of Environmental Biology, 33, 439 - 447.

Guler, M., Yomralioglu, T. \& Reis, S. (2007). Using landsat data to determine land use/land cover changes in Samsun, Turkey. Environmental Monitoring and Assessment, 127(1-3). Doi: 155-16. $10.5897 /$ SRE10.737

Ikiel, C. (2005). Rainfall regime regions in Turkey (A statistical climate study). Forest Impact on Hydrological Process and Soil Erosion Symposium, October 2005, 109-116, Yundola- Bulgaria.

Ikiel, C., Kilic, D. E. Ustaoglu, B. \& Dutucu, A. A., (2012). Analysing land cover change with RS and GIS methods in the Elmacik Mountain and its surroundings, Turkey. Energy Education Scince and Technology Part A: Energy Science and Research, 29(2), 891-900.

Ikiel, C., Ustaoglu, B., Dutucu, A. A. \& Kilic, D. E. (2013). Remote sensing and GIS-based integrated analysis of land cover change in Duzce plain and its surroundings (north western Turkey). Environmental Monitoring and Assessment, 185, 1699-1709, doi: 10.1007/s10661-012-2661-6

Jensen, J. R. (1996). Introductory digital image processing: a remote sensing perspective. 2nd Edition. Upper Saddle River, NJ: Prentice-Hall.

Kacmaz, M. (2010). Sapanca Golu Havzasinda arazi kullanimi ve mekansal degisimi. Istanbul: T.C. Istanbul Universitesi Sosyal Bilimler Enstitusu (doktara tezi).

Kacmaz, M. \& Ikiel, C. (2007) Sapanca Kirkpinar'da yerlesmenin evrimi. Sakarya Universitesi Sosyal Bilimler Dergisi, 2 , 187-208.

Kocman, A. (1993). Turkiye Iklimi, Izmir: Ege Universitesi Basimevi.

Lausch, A., Pause M., Doktor D., Preidl S. \& Schulz K. (2013). Monitoring and assessing of landscape heterogeneity at different scales. Environmental Monitoring and Assessment, 185(11), 9419-9434. doi: 10.1007/s10661-013-3262-8

Ozdemir, H. \& Turoglu, H. (2007). Landslide susceptibility assessment using GIS and RS in the Havran River Basin (Balikesir-TURKEY). The 12th Conference of the International Association of Mathematical Geology, August 26-31, ISBN 978-09734220-4-7, Begijin, China.

Ozdemir M. A. \& Bahadır, M. (2010) Uzaktan algilama ile Acigol Havzasi'nda arazi kullaniminin zamansal degisim analizi (1975-2005). The Journal Of International Social Research, 3(12) Summer.

Peng, J., Liu, Y., Shen, H., Han Y. \& .Pan, Y. (2012). Vegetation coverage change and associated driving forces in mountain areas of Northwestern Yunnan, China using RS and GIS. Environmental Monitoring and Assessment, 184, 4787-4798. doi: 10.1007/s10661-011-2302-5

Reis, S. (2008). Analyzing land use/land cover changes using remote sensing and GIS in Rize, North-East Turkey. Sensors, 8, 6188-6202. doi: 10.3390/s8106188.

Schucknecht, A., Erasmi, S., Niemeyer, I. \& Matschullat, J. (2013). Assessing vegetation variability and trends in north-eastern Brazil using AVHRR and MODIS NDVI time series. European Journal of Remote Sensing, 46, 40-59. doi: 10.5721/EuJRS20134603.

Tunay, M. \& Atesoglu, A. (2008). Cok zamanlı uydu goruntuleri ile Amasra ve yakın cevresinde ait bitki ortusu degisim analizi. Bartin Orman Fakultesi Dergisi, 10(13), 71-80.

USGS, (2014). United States Geological Survey Earth Resources Observation Systems. http://glovis.usgs.gov/ Accessed in 5 March 2014.

Ustaoglu, B. (2012). Spatiotemporal analysis of land cover change patterns in western part of the Sakarya River Delta and its surroundings in Turkey. Energy Education Science and Technology Part A: Energy Science and Research, 29 (2), 721-730. 